\title{
関節の加速度コントローラによる ロボットのモーションコントロール
}

\author{
駒田 諭* 大西公 平**
}

\section{Motion Control of Robot Manipulators by Joint Acceleration Controllers

\author{
Satoshi KOMADA Kouhei OHNISHI
}

\begin{abstract}
This paper proposes a simple and high performance motion control method of robot manipulators in task-oriented coordinates. In the proposed method, it is necessary that each joint generates the specified acceleration by the controller of each joint. To extend the result to multi-degrees-offreedom robot manipulators, the acceleration tracing orientation method (ATOM) is obtained. The ATOM is a controller design method in task-oriented coordinates. High performance position controller and hybrid position/force controller are easily realized by the ATOM. From the analyses of the controllers, it is known that the precise acceleration controller is the key to improve the performance of the ATOM. The realization of the strict acceleration controller, however, is almost impossible by using the conventional disturbance compensation methods. For example, the inverse dynamics has complicating calculation and is weak against parameter variations. A resent research about disturbance observer enables the realization of the acceleration controller. Contrary to the inverse dynamics, the observer is simple and robust against parameter variations. High performance acceleration controller is realized by the disturbance observer. The effectivness of the ATOM is shown by some experiments of a three-degrees-of-freedom robot.
\end{abstract}

Key Words : Robot manipulators, Acceleration controller, Position controller, Hybrid position/force controller, Disturbance observer

\section{1. まえがき}

多関節ロボットには重力や, 慣性変動, 摩擦力などの 様々な干渉力が存在するため高速制御や, 正確な力制御 を行らには多くの補償を必要としてきた ${ }^{1 \sim 5)}$. 従来の口 ボットの制御においては，これらの外乱を除去するため に各々の外乱を逐次計算する逆動力学を用いる方法が提 案されている3,4). しかし膨大な計算量のため,このよう なアルゴリズムを用いる産業用ロボットの実例はない。 逆動力学はクーロン摩擦などのパラメータ变動に対して ロバストではなく、さらに高性能な制御を望むのは難し い.

原稿受付 1989 年 7 月 24 日

* 三重大学工学部 ** 慶応義塾大学理工学部
もし各関節の全ての外乱を除去できれば，口ボットの 各関節は加速度指令通りの加速度を発生する加速度コン トローラとすることができる4). 各関節が加速度コント ローラとなるならば, ロボットの高性能化を計ることが 容易である.

しかし, 逆動力学を用いて各関節の外乱を取り除き加 速度コントローラを行らには計算量が多く, マイクロプ ロセッサレベルによる実現は困難である、実際に実用的 な加速度コントローラを構成するためには, 計算量が少 なくパラメータ変動に対してロバストな外乱除去方法が 必要である.インバリアンス制御の考え方を用いて外乱 を除去する方法がすでに提案されているが，実用的にそ の中に必要な加速度を測定する手段がないため実際の制 御にこの方法は使われていなかっだ). 
それに対して，関節の速度を用いてオブザーバにより 外乱を計算し，それをフィードバックすることで外乱を 除去する方法が提案され，その有効性が確認されてい る7).この方法は計算量が少なく, “汭メータ変動に対 してロバストで，ロボットの制御で一般に用いられてい る電流センサと速度検出器を用いるだけで簡単に外乱が 除去できる．このオブザーバによる方法で高速軌跡制 御8) 及びカフィードバック制御9.10) の実現が報告されて いる.

本論文ではこれを更に発展させ，ロボットの各関節を 加速度コントローラとすることにより，作業座標におい

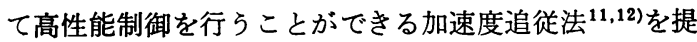
案する. まずロボットの各関節に加わる外乱を示し, 加 速度コントローラとなるための条件を検討する.さらに, ロボットの作業座標での加速度コントローラの特性を誤 差方程式により明らかにする. 次に作業座標での特性を 用いて, 位置コントローラやカコントローラを加速度追 従法に基ついて構成し，その有効性を示す．以上の制御 に用いられる加速度追従法は, 各関節が加速度コントロ ーラとなっていることが基本である. 即ち，作業座標で 加速度指令を求めるコントローラを構成して, それを等 価な関節の加速度に変換し加速度コントローラへの指令 とする. 加速度コントローラを構成するための実際的な 方法として, 加速度信号を用いる方法及び, 速度信号か ら外乱を求めるオブザーバを使ら方法を紹介し，その特 性を検討する. 最後に多自由度ロボットでの実験を通じ， その結果を比較検討することにより提案する方法の有効 性を示す.

\section{2. 加速度コントローラをもつマニピュレータ の特性}

\section{1 関節の外乱と加速度コントローラ}

トルク定数 $K_{t}$ のアクチュェータで駆動されるロボッ トの各関節のブロック線図は Fig. 1 のように表わされ

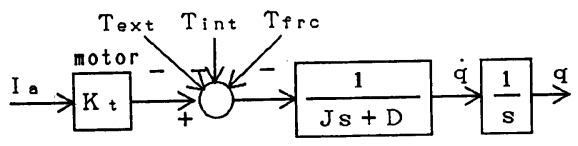

Fig. 1 Block diagram of robot joint

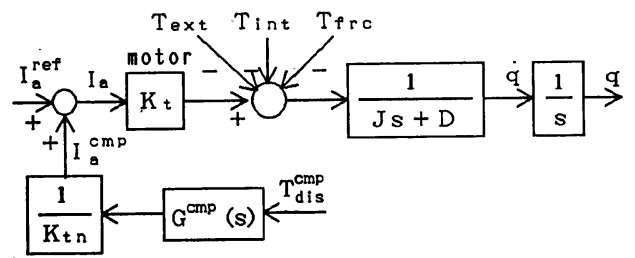

Fig. 2 Disturbance compensation of each joint
大西公平

る. $q$ は関節の角度を表わしており, 関節の速度のラブ ラス変換を $\dot{q}$, 加速度のラプラス変換を $\ddot{q}$ と定義してい る.ここでJは関節の慣性モーメント，Dは粘性係数で ある. 他に外乱として, 相互慣性力, 遠心力やコリオリ 力や重力による干渉トルク $T_{\text {int }}$, 関節の摩擦トルク $T_{f r c}$, 接触作業を行う場合の接触力 $T_{\text {ext }}$ が存在する. 関節の 動きの妨げになるこのような外乱の総和を（1）式で定 義する.

$$
\begin{aligned}
T_{d i s}^{c m p}= & T_{i n t}(\boldsymbol{q}, \dot{\boldsymbol{q}}, \ddot{\boldsymbol{q}})+\left(J-J_{n}\right) \ddot{q}+D \dot{q} \\
& +T_{f r c}+T_{e x t}+\left(K_{t n}-K_{t}\right) I_{a}
\end{aligned}
$$

ここで $J_{n}, K_{t n}$ はノミナルな定数を表わしている.（1） 式の第 1 項目は他の関節からの相互慣性力, 遠心力, コ リオリカ, 重力による干渉力である. 第 2 項目以下は自 己慣性変動力, 関節の粘性力, クーロン摩擦力, ロボッ トの接触作業による対象物からの反作用力, アクチュエ 一タのトルクリプルである.これらの外乱は関節の角度, 速度, 加速度をパラメータとして含む関数や, 複雑に変 動する変数で表現される．また，これらの外乱はマニピ ニレータの各関節に印加されるが, アクチュエータで決 まる最大トルクの範囲に関節の加減速に使われるトルク と外乱トルクの和が収まるならば, 全ての外乱を除去す ることは可能である.

各関節の外乱を抑圧するために Fig. 2 のように $T_{d i s}{ }^{c m p}$ と, ある周波数特性 $G^{c m p}(s)$ の積を $K_{t n}{ }^{-1}$ 倍 してフィードバックする. ここで, 補償されるべき外乱 を（2）式のように定義する.

$$
\begin{aligned}
T_{d i s}= & T_{i n t}(\boldsymbol{q}, \dot{\boldsymbol{q}}, \ddot{\boldsymbol{q}})+\left(J-J_{n}\right) \ddot{q}+D \dot{q} \\
& +T_{f r c}+T_{e x t}+\left(K_{t n}-K_{t}\right) I_{a}{ }^{r e f}
\end{aligned}
$$

(2) 式は (1) 式の外乱の定義式の電機子電流 $I_{a}$ に対 するトルクリプルの項を, 電流指令值 $I_{a}{ }^{r e f}$ に対するも

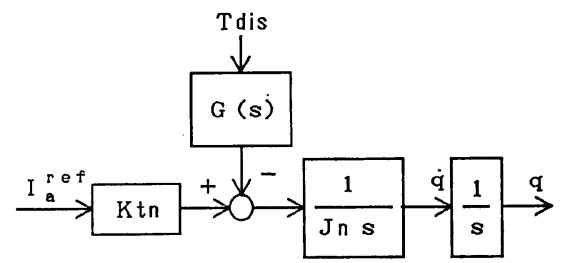

Fig. 3 Equivalent performance of disturbance compensated system

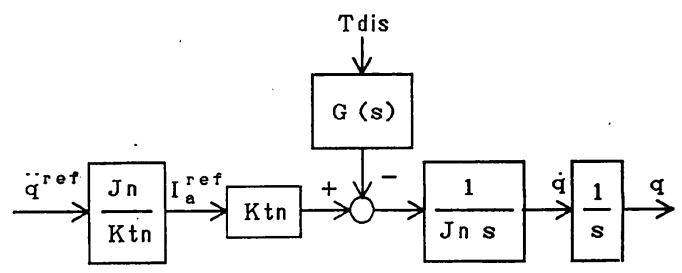

Fig. 4 Block diagram of acceleration controller 
のに変えている. この様な外乱の定義に基づいて Fig. 2 のブロック線図を変換すると Fig. 3 となる.ここで, (2) 式の外乱の関節に対する影響 $G(s)$ は,

$$
G(s)=\frac{1-G^{c m p}(s)}{1-G^{c m p}(s)\left(1-\frac{K_{t}}{K_{t n}}\right)}
$$

となる. 従って, $|G(j \omega)|$ がなるべく小さくなるように $G^{c m p}(s)$ を選ぶことでロボットの性能の向上が計れる.

Fig. 3 のよ5にトルク定数と慣性モーメントが公称值 に固定されているならば, Fig. 4 のように加速度指令 值の $J_{n} / K_{t h}$ 倍を電流指令值 $I_{a}^{r e f}$ とすることによっ て加速度コントローラが実現される.このときの周波数 領域での加速度の応答は (4) 式で示される.

$$
\ddot{q}=\ddot{q}^{r e f}-\frac{G(s)}{J_{n}} T_{d i s}
$$

この式から, 外乱の影響がないか無視できるほど小さい ならば，各関節は加速度指令通りの加速度の応答が得ら れることがわかる.また，この式を時間領域に変換する と,

$$
\ddot{q}(t)=\ddot{q}^{r e f}(t)-p(t)
$$

となる.ここで抑圧外乱加速度 $p(t)$ は外乱の影響を示 す要素で, 逆ラプラス変換によって

$$
p(t)=\mathcal{L}^{-1}\left[J_{n}{ }^{-1} G(s) T_{d i s}\right]
$$

と定義される.

\section{2 作業座標での加速度コントローラ}

ロボットの関節の角度を表わすマニピュレータの一般 化座標 $\boldsymbol{q}$, 作業座標における 3 自由度並進と 3 自由度回 転を表わす $\boldsymbol{x}$ の関係は順運動学の座標変換 $\boldsymbol{L}(\cdot)$ によ って (7) 式で関係付けられる.

$$
\boldsymbol{x}=\boldsymbol{L}(\boldsymbol{q})
$$

これを微分することによって速度, 加速度の関係は次式 となる.

$$
\begin{aligned}
& \dot{\boldsymbol{x}}=\boldsymbol{J}_{a c o} \dot{\boldsymbol{q}} \\
& \dot{\boldsymbol{x}}=\boldsymbol{J}_{a c o} \ddot{\boldsymbol{q}}+\dot{\boldsymbol{J}}_{a c o} \dot{\boldsymbol{q}}
\end{aligned}
$$

ここで $\boldsymbol{J}_{a c o}$ はマニピュレータのヤコビ行列を表わして いる.（7)，（8）式は関節座標での 位置と速度を作業 座標での位置と速度に変換する. (9) 式を変形して作 業座標における加速度指令を関節の加速度指令に变換す る式を（10）式とする.

$$
\ddot{\boldsymbol{q}}^{r e f}=\boldsymbol{J}_{a c o^{-1}}\left(\boldsymbol{x}^{r e f}-\dot{\boldsymbol{J}}_{a c o} \dot{\boldsymbol{q}}\right)
$$

一方, 各関節が（5）式のように外乱の補償がなされて いるならば, マニピュレータの一般化座標における式は 次のようになる.

$$
\ddot{\boldsymbol{q}}=\ddot{\boldsymbol{q}}^{r e f}-\boldsymbol{p}
$$

ここで, $\boldsymbol{p}$ は各関節の外乱の影響を表わす加速度べクト ルであり（6）式から求まったものである.この $\boldsymbol{p} を$ 抑圧外乱加速度べクトルと呼ぶことにする.（10)式によ
って各関節の加速度指令が算出されるので，これを(11) 式に代入すると,

$$
\ddot{\boldsymbol{q}}=\boldsymbol{J}_{a c o}{ }^{-1}\left(\ddot{\boldsymbol{x}}^{r e f}-\dot{\boldsymbol{J}}_{a c o} \dot{\boldsymbol{q}}\right)-\boldsymbol{p}
$$

となる．上式を変形して（9）式の関係を用いれば

$$
\ddot{\boldsymbol{x}}=\boldsymbol{x}^{r e s}-\boldsymbol{J}_{a c o} \boldsymbol{p}
$$

となり作業座標の関係が得られる.ささらに（13)式を変 形すれば (14) 式となり,これは作業座標における加速 度誤差を表わす.

$$
\ddot{\boldsymbol{x}}^{r e f}-\ddot{\boldsymbol{x}}=\boldsymbol{J}_{a c o} \boldsymbol{p}
$$

（14）式は作業座標の加速度誤差が 各関節の 抑圧. 外乱加 速度ベクトルをヤコビ行列で各座標に分配した形で表わ されることを示している.このとき $J_{a c o}$ は $X Y$ テーブ ルなどのマニピュレータを除いて一般的に対角行列とは ならないため, 抑圧外乱加速度べクトル $\boldsymbol{p}$ の各要素が零 とならなければ, 作業座標での各方向の加速度応答はヤ コビ行列を通じてあらゆる関節の外乱の影響を受けるこ とがわかる. また, 抑庄加速度外乱ベクトル $\boldsymbol{p}$ が無視で きるほど小さければ作業座標での加速度指令通りの加速 度となることがわかる。

\section{3. 加速度追従法 ${ }^{11)}$}

加速度追従法 (Acceleration Tracing Orientation Method : ATOM) は各関節が加速度指令通りの加速度 を発生することを前提とするロボットの制御方法であり, その概略は以下の通りである.

(1) ロボットの各関節を加速度指令に追従する加速度 コントローラとする.

(2) 作業座標でいくつかのコントローラを構成し加速 度指令を計算する。

(3) 作業座標での加速度指令の和をそれと等洒な関節 座標での加速度に変換し, 加速度コントローラの指令と する.

前章での考察により, 各関節が加速度コントローラで あれば作業座標での加速度指令通りの加速度応答が得ら れるので, この方法でコントローラを構成すれば高速な 作業座標での応答を期待できる. 次に制御系を構成する いくつかの実例を示す.

\section{1 位置コントローラ}

加速度追従法に基ついて位置コントローラを構成する と Fig. 5 となる.このコントローラは作業座標におい て位置, 速度, 加速度ベクトルの 3 つを指令入力として いる．作業座標での位置と速度べクトルは関節座標での 位置, 速度ベクトルから（7），（8）式によって各々求 まる. $K_{1}, K_{2}$ は各々速度偏差, 位直偏差のゲイン対角 行列である. 作業座標では次式のように加速度指令べク トルを計算する。 
276

$$
\begin{aligned}
\ddot{x}^{r e f}(t)= & \boldsymbol{x}^{c m d}(t)+K_{1}\left(\dot{\boldsymbol{x}}^{c m d}(t)-\dot{\boldsymbol{x}}(t)\right) \\
& +\boldsymbol{K}_{2}\left(\boldsymbol{x}^{c m d}(t)-\boldsymbol{x}(t)\right)
\end{aligned}
$$

この作業座標の加速度指令を（10）式を用いて関節座標 での加速度指令べクトルに変換する. この加速度追従法 に基づく位置コントローラの特性を検討するために，

（15）式を作業座標での加速度コントローラの特性を示

す（13）または（14）式に代入すると,

$$
\begin{aligned}
& \left(\dot{\boldsymbol{x}}^{c m d}-\dot{\boldsymbol{x}}\right)+\boldsymbol{K}_{1}\left(\dot{\boldsymbol{x}}^{c m d}-\dot{\boldsymbol{x}}\right)+\boldsymbol{K}_{2}\left(\boldsymbol{x}^{c m d}-\boldsymbol{x}\right) \\
& =\boldsymbol{J}_{a c o} \boldsymbol{p}
\end{aligned}
$$

となる. 従って, 石辺の外乱の項が 0 または無視できる ほど小さいならば指令通りの位置, 速度, 加速度応答が 得られ，定常的にも過渡的にも指令に追従する．また， 作業座標の各方向間の干渉もない.

これをラプラス領域で表現すると（17）式となる.

$$
\left(\boldsymbol{S}^{2}+\boldsymbol{K}_{1} \boldsymbol{S}+\boldsymbol{K}_{2}\right)\left(\boldsymbol{x}^{c m d}-\boldsymbol{x}\right)=\mathcal{L}\left[\boldsymbol{J}_{a c o} p\right]
$$

ここで $\boldsymbol{S}$ はラプラス演算子 $s$ を要素として持つ対角行列 を表わしている．また，ブロック図で表現すれば Fig. 6 となる.ここで $\boldsymbol{J}_{n}$ は各関節の公称慣性モーメントを, $\boldsymbol{G}$ は外乱の除去特性をそれぞれ対角要素として持つ行列 を表わしている. $\boldsymbol{t}_{d i s}$ は各関節の外乱 $T_{d i s}$ を示すべク トルである.この様に外乱の項には非線形なヤコビ行列 が存在するが，その他は作業座標で線形な関係で表わす ことができる．従って外乱が零かまたは無視できるほど 小さいならば，作業座標において線形コントローラが構 成できる，p=0 であれば（17）式右辺は０となり，

$$
\operatorname{det}\left(\boldsymbol{S}^{2}+\boldsymbol{K}_{1} \boldsymbol{S}+\boldsymbol{K}_{2}\right)=0
$$

の全ての固有値が複数平面の左半平面に存在すれば, 安 定に位置指令と同じ位置の応答が得られる．また，

$$
\lim _{\boldsymbol{s} \rightarrow \mathbf{0}} \boldsymbol{S} \mathcal{L}\left[\boldsymbol{J}_{\text {aco }} \boldsymbol{p}\right]=0
$$

ならば

$$
\lim _{s \rightarrow 0}\left(\boldsymbol{S} \boldsymbol{x}^{c m d}-\boldsymbol{x}\right)=\mathbf{0}
$$

となる応答が得られる，過渡䛊差は（18）式で示される コントローラの固有值と（17）式で示される外乱に対す る特性の相互作用によって決まる.（19）式から, 外乱 除去特性 $G(s)$ は収束性の良い, カットオフ周波数の高

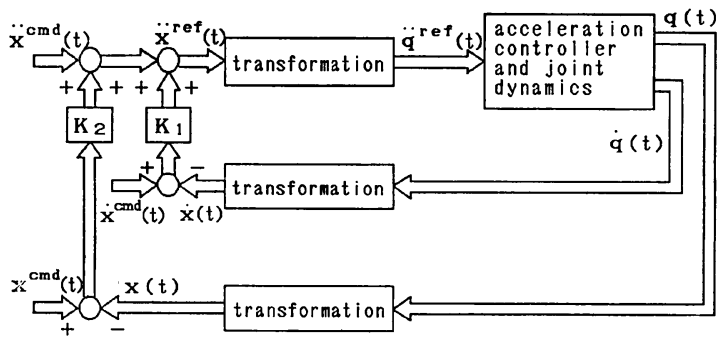

Fig. 5 Multi-degrees-of-freedom position controller based on the acceleration tracing orientation method
大西公平

いハイパスフィルタが要求される．具体的な設計例は後 節で示す。

\section{2 位置とカのハイブリッドコントローラ5)}

前節と同様に加速度追従法で位置と力のハイブリッド コントローラを構成する場合を Fig. 7 に示す. 図の上 側は新しく加わったカコントローラで, 下側はFig. 5 で 示した位置コントローラである.ここで $\boldsymbol{H}$ はコンプラ イアンス選択対角行列であり，その対角要素により位置 制御, 力制御の選択をする. すなわち, 対角要素が 1 な らばその方向に位置制御を行い，逆に0ならば力制御を 行う. カコントローラでは力偏差を任意の対角質量行列 $\boldsymbol{M}$ の逆行列を用いて加速度指令としている. このとき の作業座標の加速度指令は,

$$
\begin{aligned}
\dot{\boldsymbol{x}}^{r e f}(\boldsymbol{t})= & \boldsymbol{H}\left\{\dot{\boldsymbol{x}}^{c m d}(\boldsymbol{t})+\boldsymbol{K}_{1}\left(\dot{\boldsymbol{x}}^{c m d}(\boldsymbol{t})-\dot{\boldsymbol{x}}(\boldsymbol{t})\right)\right. \\
& \left.+\boldsymbol{K}_{\mathbf{2}}\left(\boldsymbol{x}^{c m d}(\boldsymbol{t})-\boldsymbol{t}(\boldsymbol{x})\right)\right\} \\
& +(\boldsymbol{I}-\boldsymbol{H})\left\{\boldsymbol{M}^{-1}\left(\boldsymbol{f}^{c m d}(\boldsymbol{t})-\boldsymbol{f}(\boldsymbol{t})\right)\right. \\
& \left.-\boldsymbol{K}_{1} \dot{\boldsymbol{x}}(\boldsymbol{t})\right\}
\end{aligned}
$$

となっている. 上式の右辺第 2 項目は力制御の加速度指 令を計算しており, 速度フィードバックは力制御の安定 化のために加えられている．加速度追従法に基づく位置 コントローラの解析は前節で行ったので,ここではカコ ントローラの解析を行う。（21）式と（13）または（14） 式から次の関係が求まる.

$$
\boldsymbol{M}^{-1}\left(\boldsymbol{f}^{c m d}-\boldsymbol{f}\right)-\left(\dot{\boldsymbol{x}}+\boldsymbol{K}_{\mathbf{1}} \dot{\boldsymbol{x}}\right)=\boldsymbol{J}_{a c o} \boldsymbol{p}
$$

力制御の力の応答は力を加える物体の特性によって影響 を受ける. そこで, 力を加える対象をバネ係数 $\boldsymbol{K}_{e}$ と粘 性係数 $\boldsymbol{D}_{e}$ でモデル化すると力の応答は,

$$
\boldsymbol{f}=\boldsymbol{D}_{e} \dot{\boldsymbol{x}}+\boldsymbol{K}_{e} \boldsymbol{x}
$$

となる、ただし，ここでの $\boldsymbol{x}$ は力を加えた対象物体の押 下距離を表わしている.（22）式に（23）式を代入する と,

$$
\begin{gathered}
\boldsymbol{M}^{-1} \boldsymbol{f}^{c m d}-\left\{\ddot{\boldsymbol{x}}+\left(\boldsymbol{M}^{-1} \boldsymbol{D}_{e}+\boldsymbol{K}_{\mathbf{1}}\right) \dot{\boldsymbol{x}}+\boldsymbol{M}^{-1} \boldsymbol{K}_{e} \boldsymbol{x}\right\} \\
=\boldsymbol{J}_{a c o} \boldsymbol{p}
\end{gathered}
$$

となり, 力指令 $\boldsymbol{f}^{c m d}$ に対する位置の応答 $\boldsymbol{x}$ が求まり, それを（23）式に代入すれば力の応答が得られる.この 式より, 右辺の外乱の影響が十分に小さければ定常的に

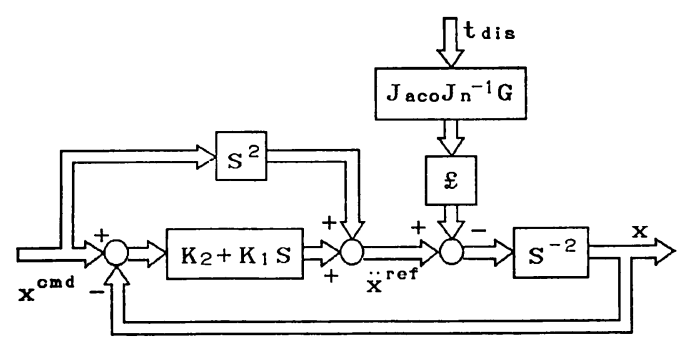

Fig. 6 Block diagram of position controller in task-oriented coordinates 


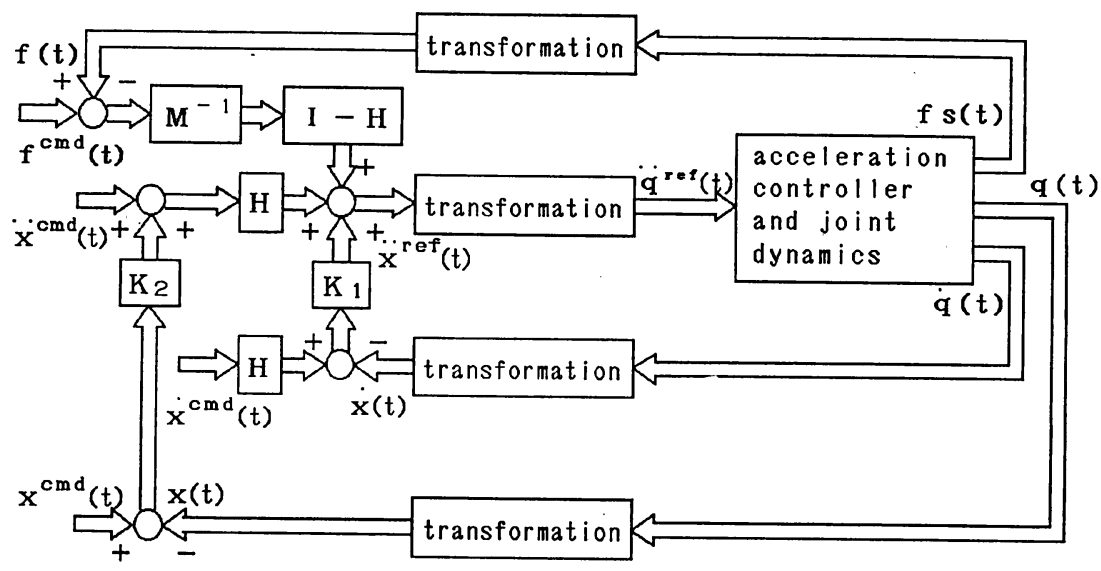

Fig. 7 Hybrid position/force controller based on the acceleration tracing orientation method

力指令どおりの力の応答が得られることがわかる.ささら に，力を加える物体の特性がわかっているならば力制御 の動特性も自由に決めることが可能である．また，前節 の位置コントローラと同様に作業座標でも各方向の干渉 はないことがわかる.

位置コントローラと同様に，このカコントローラを周 波数領域で表現すると Fig. 8 となる.この図より, 対 象が（23）式で表わされる限り外乱以外㤬て線形とな ることがわかる.（23）式と（24）式から力指令と力の応 答の関係は

$$
\boldsymbol{f}^{c m d}-\frac{\boldsymbol{M} \boldsymbol{S}^{2}+\left(\boldsymbol{D}_{e}+\boldsymbol{M} \boldsymbol{K}_{1}\right) \boldsymbol{S}+\boldsymbol{K}_{e}}{\boldsymbol{D}_{e} \boldsymbol{S}+\boldsymbol{K}_{e}} \boldsymbol{f}=\boldsymbol{M} \mathcal{L}\left[\boldsymbol{J}_{a c o} \boldsymbol{p}\right]
$$

となる.これによって力を加える対象の動特性からコン トローラのパラメータを求め, さらに (19) 式のように 外乱の影響が除去できるならば，所望の応答を実現する ことが可能である.

\section{4. 外乱の除去方法}

外乱の除去方法としては逆動力学を用いるのが一般的 であるが，この方法で（2）式の外乱全てを取り除くこ とは計算量の点で実用的ではなく, 摩擦力のようなパラ メータ変動に対して弱いなどの欠点がある.ここでは加 速度情報に基づく外乱補償方法を用いることにする.

\section{1 関節の加速度を用いる場合}

Fig. 9 のように各関節の加速度と電機子電流を用い て計算すると $G^{c m p}(s)=1$ となり，(1) 式の外乱を遅 れなく計算できる゙). そしてその值をつィードバックす ると Fig. 3, Fig. 4 の外乱に対する伝達関数 $G(s)$ は （3）式より零伝達関数になり, 外乱の影響が零になる. 従って位置コントローラの（16), (17) 式の右辺と力コ

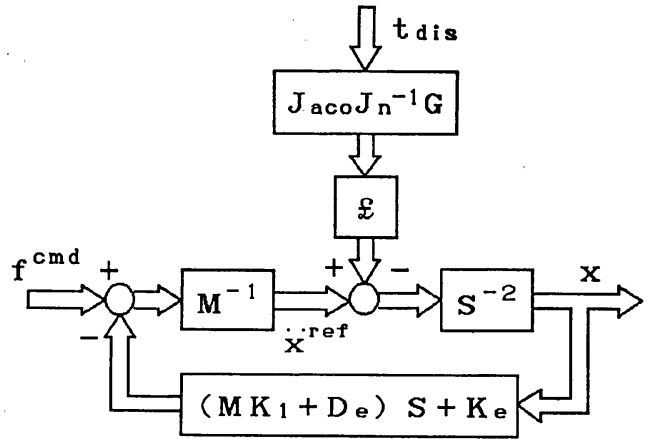

Fig. 8 Block diagram of force controller in task-oriented coordinates

ントローラの (24), (25) 式の右辺の外乱の項が全て 0 となり，作業座標の各方向での干渉はまったく見られな い.この方法は外乱除去方法としては理想的なものであ るが，実際にロボットの制御に適用されていない，角加 速度を求めるには加速度計を用いる方法が考えられるが, 理想的な加速度計は現状では難しい，また，タュジェネ レータの微分ではノイズのない加速度を得ることは不可 能である.これらの理由から，この方法で加速度コント ローラを構成することは現状では難しいといえる．

\section{2 関節の速度を用いる場合}

加速度を用いると前節のように理想的なコントローラ が構成できる. しかし, 実際に加速度を測定するには困 難が伴う. そこで, 速度検出器を用いて外乱を除去する 方法を示す. Fig. 10 では (1) 式の外乱を

$$
G^{c m p}(s)=\frac{g}{s+g}
$$

の様に一次遅れで計算する最小次元オブザーバを用いて いる7). 計算された外乱をフィードバックすると Fig. 3, 


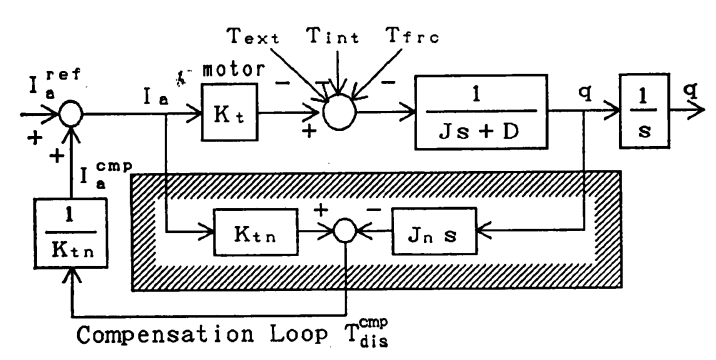

Fig. 9 Block diagran of disturbance compensation by joint acceleration signal

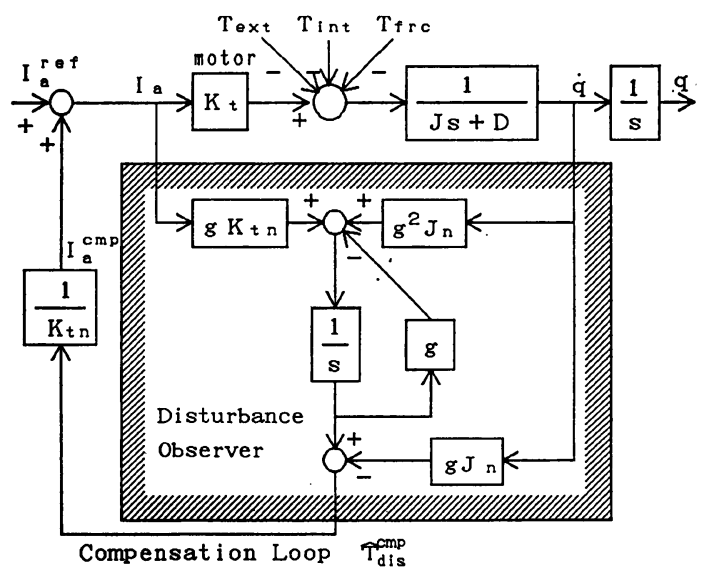

Fig. 10 Block diagram of disturbance compensation by disturbance óbserver

Fig. 4 の外乱に対する伝達関数 $G(s)$ は,

$$
G(s)=\frac{s}{s+g^{\prime}}
$$

の低域遮断フィルタとなる.ここで $g^{\prime}$ は

$$
g^{\prime}=\frac{K_{t}}{K_{t n}}
$$

となっている. 従って遮断周波数 $g^{\prime}$ が外乱の周波数成 分よりも十分大きければ，外乱の影響はほとんど零とみ なしても差し支えない. 特に, 定常的な外乱は $G(0)=0$ といら性質によって $g^{\prime}$ にかかわらず零に収束する.才 ブザーバの遮断周波数の上限は速度検出器のノイズによ り制限されるため, 制御系の要求する性能に応じて速度 検出器を選択する必要がある. 外乱オブザーバはここで 紹介した 1 次元オブザーバだけでなく次数の高いオブザ 一バとすることも可能である ${ }^{13)}$. 以下ではこの 1 次元オ ブザーバで加速度追従法を実現している.

\section{5. 実 験 結 果}

加速度追従法の特性を実験で明らかにするため, Fig. 5, Fig. 7 の位置コントローラ, 位置とカの八イブリッド コントローラをFig. 11 の 3 自由度ロボットに適用する.

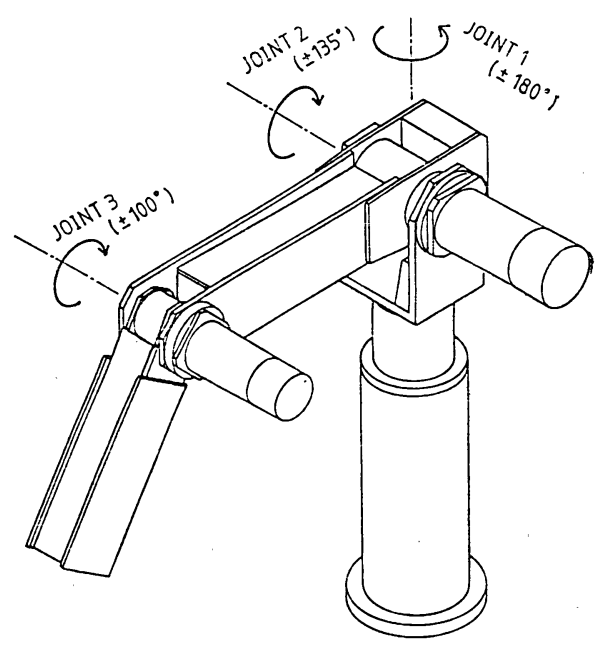

Fig. 11 Tested manipulator

Fig. 12 のように座標の原点をロボットの先端の目標位 と置とし，その座標の方向を $x, y, z$ の 3 自由度並進に る. ロボットの先端には 3 自由度力センサが取り付けら れ，3方向の力を測定する.ここではFig. 13 のよらな 姿勢で実験を行い，ハイブリッド制御では垂直な壁に先 端を接触させて実験を行った. システム構成は Fig. 14 のようになっている. 各関節の $16 \mathrm{bit} 8086 \mathrm{CPU}$ はオブ ザーバで外乱補償を行い，直流サーボモータに指令を 与える. その他の作業座標でのコントローラ, 座標変換 は DSP (NEC- $\mu$ PD 77230 digital signal processor) で計算され，各関節の $8086 \mathrm{CPU}$ 一指令を出す.

オブザーバのカットオフ周波数を約 $700 \mathrm{rad} / \mathrm{sec}$, サ ンプリングタイムを $1 \mathrm{msec}$ とした．位置コントローラ の $K_{1}, K_{2}$ の対角要素はそれぞれ $90 \mathrm{sec}^{-1}, 2,000 \mathrm{sec}^{-2}$, カコントローラの質量行列 $\boldsymbol{M}$ の対角要素は $10 \mathrm{~kg}$ とし. た.

加速度追從法に基づくロボットの制御の実験を行っ た. Fig. 15 は $y$ 方向に位置制御を行ったときの位置・ 速度の指令とそれらの応答を示している. 速度の過渡応 答で少し偏差が存在するが，その他では遅れなく指令に 追従している. Fig. 16 は Fig. 15 の実験に $z$ 方向の力 制御を加えてハイブリッド制御にし，同時に各々の指令 値を変化させた結果である. 上側は力指令と力の応答で あり, 指令に対してほぼ同じ力が発生している. 下側の 位置指令と位置の応答は重なって測定されている. ま た，力制御と位置制御の間には干涉とみられるような応 答がない，このことから加速度追従法に基づく制御法は 外乱に対してロバストで応答性が良く, 作業座標の各方 向での干渉はほとんどないことが確認された。 


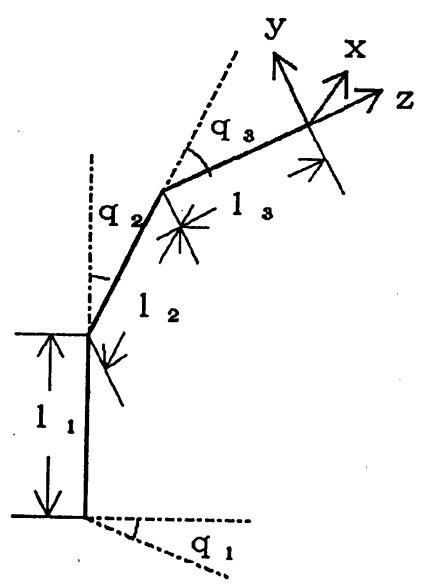

Fig. 12 Schematic figure of tested robot

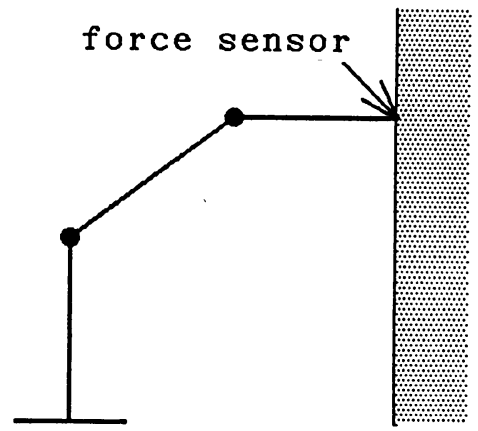

Fig. 13 Experimental method

Host Computer Sub Computers Manipulator

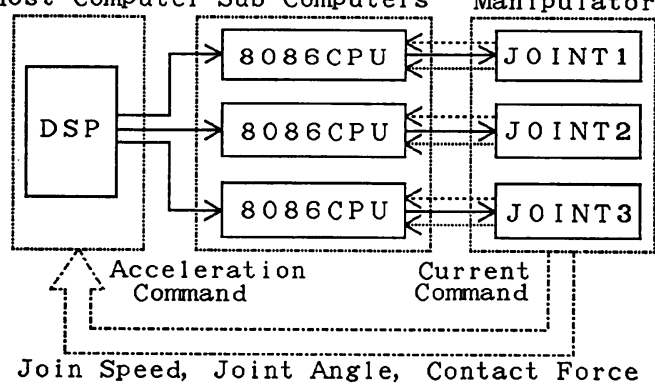

- Armature Current -........Speed

Fig. 14 Total system of robot control

\section{6. 結 铪}

ロボットの各関節を加速度指令通りの加速度を発生す ることができる加速度コントローラとする方法を提案し た.これを作業座標に拡張した加速度追従法を提案し, 位置コントローラと位置とカのハイブリッドコントロー ラを実例として示した.このコントローラの特徵は応答 性がよく, 外乱に対してロバストでュントローラの構成

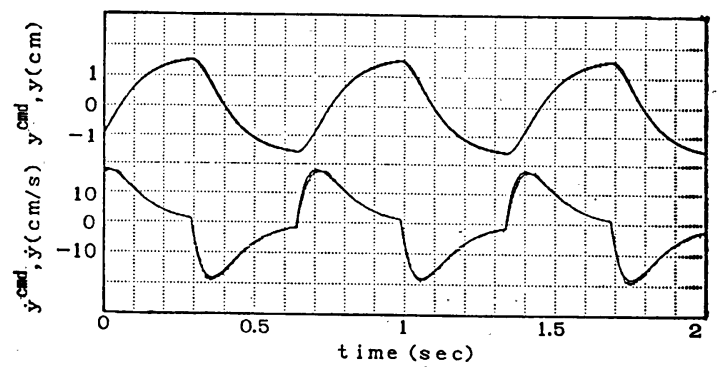

Fig. 15 Experimental result of position controller

upper side : position command and response lower side : speed command and response

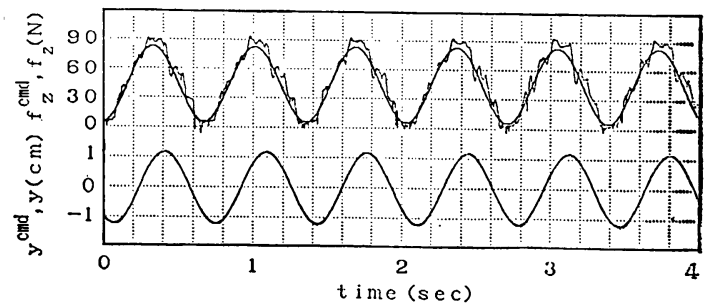

Fig. 16 Experimental result of hybrid position/force control

upper side : force command and response lower side : position command and response

が簡単なことである.ささらに，作業座標の各方向で別の コントローラを構成した場合でも, 各軸間の干渉が存在 しないといらことも特徵の一つである.ここでは各関節 を加速度コントローラとするために, 計算が簡単でパラ メータ変動に強い外乱オブザーバを用いる方法を提案し た.これらの特徵をロボットマニピュレータの実験で確 認し，有用性を示した。

\section{参考文献}

1) Paul, R.P., "Robot Manipulators-Mathematics, Programming, and Control", pp. 209, MIT Press, 1981

2) Luh, J.Y.S., "Conventional Controller Design for Industrial Robots-A Tutorial-”, IEEE Trans. Syst., Man Cybernetics, VolSMC-13-3, pp. 298-316, 1984

3) Freunt, E., "Fast Nonlinear Control with Arbitrary Pole-Placement for Industrial Robots and Manipulators", Int. J. Robotic Research, Vol 1-1, pp. 6578, 1982

4) Luh, J. et al., "Resolved-Acceleration Control of Mechanical Manipulators", IEEE Trans. Automatic Control, Vol.AC-25-3, pp. 468-474, 1980

5) Raibert, M.H., "Hybrid Position/Force Control of Manipulators", Trans. ASME J. Dynamic Systems, Measurement, and Control, Vol.102, pp. 126-133, 1981

6) Hewit, J.R. et al., "Dynamic Coordination of Robot Movement", 4 th CISM IFTOMM Int. Symp. 
on Theory and Practice of Robots and Manipulators Ro-Man-Sy, pp. 77-88, 1981

7) Nakao, M. et al., “A Robust Decentralized Joint Control Based on Interference Estimation", Proc. IEEE Int. Conf. Robotics and Automation, Vol 1, pp. 326-331, 1987

8) Hoshinaka, T. et al., "Fast Motion Control of Mechanical Manipulator for Path Tracking", Proc. IEEE Int. Conf. IECON '88, Vol1, pp. 163-168, 1988

9) Komada, S. et al., "Robust Force and Compliance Control of Robotic Manipulator", Proc. IEEE Int. Conf. IECON '88, Vol.1, pp. 20-25, 1988

（0）駒田他，“加速度に基つく多自由度ロボットのカフィー ドシック制御”, 電気学会論文誌D分冊, Vol 109-5, pp.
325-332, 1989

11) Komada, S. et al., "Force Feedback Control of Robot Manipulator by Acceleration Tracing Orientation Method", IEEE Trans. Ind. Electron., Vol IE-37pp. 6-12, 1989

12) Ohnishi, K. el al., "Applications of Advanced Control Techniques in Electrical Drives", Proc. Int. Workshop on Microcomputer Control of Electric Drives, A1, 1989

13) Umeno, T. et al., "Generalized Robust Servo-system Design Besed on the Parameterization of Two Degrees of Freedom Controllers", Proc. IEEE PESC '89, pp. $945-951,1989$

Table 1 Nomenclature

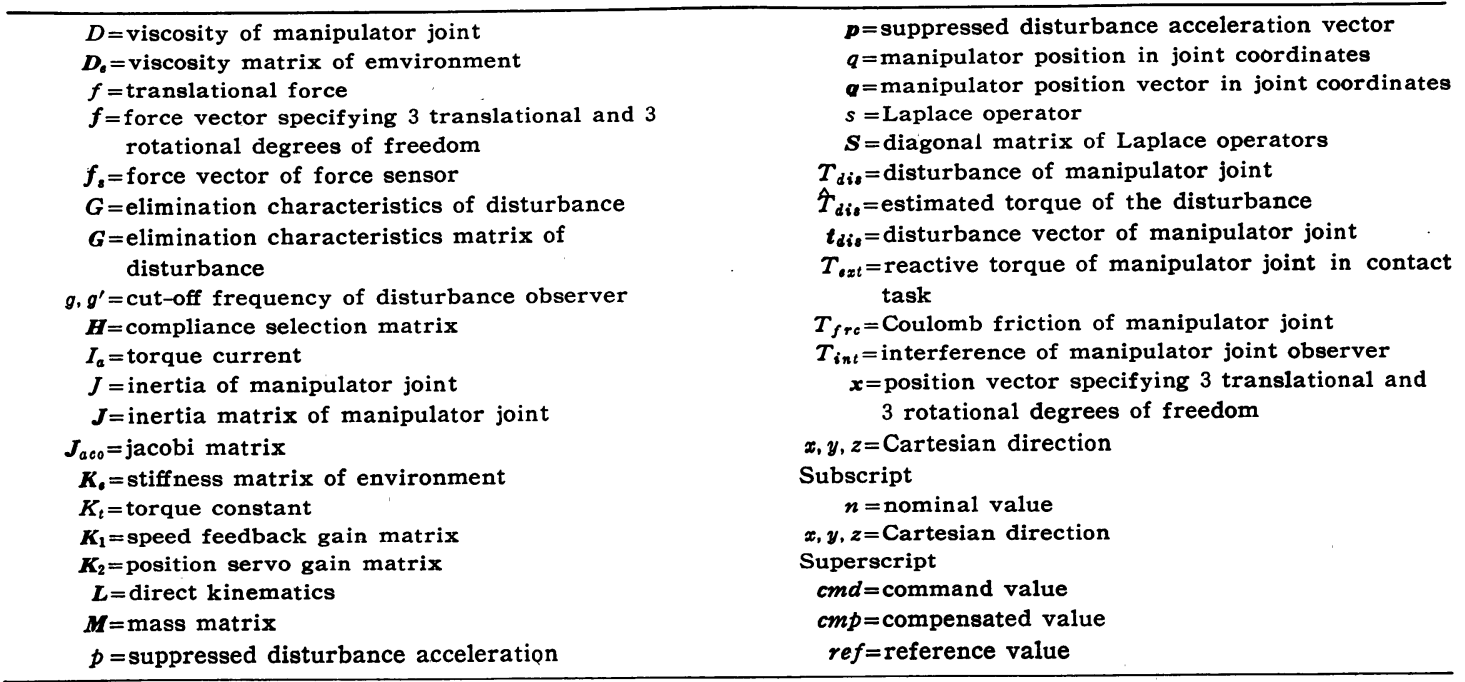

